\title{
When Politics Allied with Religion: Russia's New Strategy to Dominate the Middle East under the Pretext of Fighting Terrorism
}

\author{
Hichem Kadri1, Elmira Akhmetova² \\ ${ }^{1}$ Department of Political Science, International Islamic University Malaysia, Gombak, Selangor, Malaysia \\ ${ }^{2}$ Department of History and Civilization, International Islamic University Malaysia, Gombak, Selangor, Malaysia \\ Email: hichem.kadri@live.iium.edu.my, hichemphd@gmail.com, elmira@iium.edu.my, eakhmetova@gmail.com
}

How to cite this paper: Kadri, H., \& Akhmetova, E. (2020). When Politics Allied with Religion: Russia's New Strategy to Dominate the Middle East under the Pretext of Fighting Terrorism. Open Journal of Political Science, 10, 185-203.

https://doi.org/10.4236/ojps.2020.102013

Received: January 21, 2020

Accepted: March 2, 2020

Published: March 5, 2020

Copyright (๑) 2020 by author(s) and Scientific Research Publishing Inc. This work is licensed under the Creative Commons Attribution International License (CC BY 4.0).

http://creativecommons.org/licenses/by/4.0/

\begin{abstract}
The purpose of this article is to provide a critical approach to Russia's new policy of alliance with its dominant religion that is embodied in the Russian Orthodox Church (ROC), which Russia has thus far embraced to fight terrorism and extremism in the Middle East and to determine the extent to which religion stands with politics in Russia's foreign policy. Syria is taken as a case study and as an eminent example of Russia's anti-terror front strategy. The main argument of the paper is that Russia's leading role on the anti-terror front in the Middle East is a security-oriented and national identity-founded strategy under the pretext of fighting terrorism, while it looks forward to being a dominant power in regional, then world affairs. It finds that Russia employs the ROC in political terms as a soft power tool for promoting its foreign policy, as a way to achieve its national interests and to guarantee its national security.
\end{abstract}

\section{Keywords}

Anti-Terror Front, Sphere of Influence, Terrorism and Extremism, Middle East, ROC, Russia's Foreign Policy

\section{Introduction}

Religion clearly contributes to the shaping of states' foreign policies and international relations. Religions need to be studied in the context of the tools of political affairs. Geopolitics is considered one of these tools. The relationship between politics and religion can be clearly seen in reality, such as how the Sunni and Shi'a conflict is operated both politically and ideologically by Saudi Arabia and 
Iran, from the first Gulf War to the invasion of Iraq in 2003, and the actual Yemeni and Syrian crises, which are clear proof of the conflict to dominate and extend their spheres of influence in the Muslim World and particularly in the Middle East. To some extent, Russia's secular regime orients its foreign policy to its religion, Orthodox Christianity, as a strategy to achieve its national interest to become a superpower once again. Graziano suggests that any religion could become the object of political exploitation, for purposes that have nothing to do with the salvation of the soul (Graziano, 2018). De facto, Russia has changed significantly since the collapse of the Soviet Union, which was known for the propagation of Communist ideology. In the post-Soviet era, Russia's foreign policy direction is far from being ideological. The foreign affairs policy of states is based on self-interest strategies to achieve goals and protect their national interests in world affairs. Russia's foreign policy is focused on a set of essential objectives such as securing its military bases abroad and guaranteeing strong economic growth. One thing which remains steady is the delusion of grandeur that is still defining the insatiable desire of Russia to achieve its geopolitical ambitions and expand its sphere of influence.

After the demise of the Soviet Union, the new Russia was politically, economically and even socially weak and unstable. Lacunae in many fields were left by this sudden demise. Russian leaders were anxiously looking to reestablish Russia as a superpower as it was earlier. Thus, many strategies were considered. By developing what is known as religious diplomacy as soft power, Russia is pragmatically endeavoring forward to reasserting its status in world politics, as a fit way to build a new civilizational milieu, or at least to recapture its Soviet grandeur and nostalgia. Russia wants to extend its geopolitical discourse from Eurasia to the Middle East under many pretexts, such as leading the anti-terror front, in parallel with Russo-American relations that are volatile as sometimes rivals in terms of the sphere of influence, and at other times somewhat cooperative in the War on Terror.

This article is critically aiming at determining the extent to which religion, particularly the Russian Orthodox Church (ROC) leadership, influences the decision-making process of Russia's foreign policy. In brief, it studies the real relationship between Russia's foreign policy and the ROC. The post-Soviet period recognized a new rise of religious discourse in Russia's foreign policy, which during the Communist system of the Soviet Union religion was extremely marginalized. The ROC has become an active advertiser of traditional values to support and bless War on Terrorism and extremism led by Russia, particularly in the Middle East, where the vast majority of its population are Muslims, under the ROC's pretext of protecting the Christain minorities, especially in Iraq and Syria. One must question why and how the Orthodox Church declared its supportive position to the War on Terrorism and consider it as a holy war, and how Russian leaders take this declaration as an opportunity to guarantee Russian national security against international threats while extending its sphere of influence and finding a new geopolitical milieu in world politics. The main argument 
of this study is that Russia's anti-terror front in the Middle East, and particularly in Syria, is national identity-based. A security-oriented strategy aims for Russia to be a dominant power by getting deeply involved in the region under the pretext of fighting terrorism. Wargas (2015) argues that one of the main reasons behind the Russian military intervention in Syria is protecting Christian minorities there. Thus, Russia's foreign policy goes hand in hand with the ROC to achieve this goal. Religious diplomacy as a form of soft power or soft diplomacy (Curanovic, 2012) is the first conceptual part of this study, while hard power in terms of declaring a War on Terror is the second part.

Russia made the soft power game an essential pillar in its endeavoring to recapture its status, although Russia came late to this game (Rutland \& Kazantsev, 2016). Russia's soft power is under extensive academic and governmental scrutiny for years, particularly that related to Russia's intentions of enabling its non-military influence in the post-Soviet sphere of influence (Cheskin, 2017).

Since 2004/2005, Russia's draconian military actions took place, passing the cases of Ukraine, Georgia, and Syria. Ukraine with the Orange Revolution in 2004 and in the 2014 crisis with a Russian military intervention to annex Crimea. Russia's aggressive reaction to Georgia in 2008 declared Russia's reemergence as a military power. The main pretext behind Russia using hard power was due to Georgia's aggression against South Ossetia. In fact, both conflicts' roots (Ukraine and Georgia) go back to the early 1990s. While in Syria, Russia began a military intervention on 30 September 2015, to support Bashar al-Assad's government. These three cases reflect the negative stereotypes of Russia as hard power and confirm Russia's failure to enhance soft power in its political engagements.

Curanovic (2012) argues that Russia functions religious diplomacy on the international stage by providing its support to soft diplomacy. To be brief, soft diplomacy refers to when NGOs (as religious institutions) promote relationships with other peer groups from all over the globe, which accordingly helping improve the image of their country. Laine and Saarelainen (2017) argue that the Russian officials and the Russian Orthodox Church have both internally and externally used spiritual aspects in their public diplomacy (For further findings see: Curanovic, 2012; Tserpitskaya, 2005; Pavlovich, 2007).

\section{Religion in Russia's Foreign Policy}

In a process of democratization shaped by political engagement in post-communist Russia, religion and the Orthodox Church took their place in foreign policy decisions and were brought up in political operations, engaging in acts which might influence the operations of the political system and its foreign policy to intervene in various external issues in searching of its national interests. Russian leaders use the ROC as a tool for their foreign policy, and these leaders under Putin's administration have returned to the church land and property seized by the communist government. Some Western secularists look at this church approval as the church becoming Russia's marionette, helping Putin to remain in 
power even though many domestic challenges such as the decrease in oil prices.

Throughout the wave of democratization that was to appear few years before the collapse of the USSR, Gorbachev's administration adopted new political and economic policies that were to change the way of thinking of both political leaders and citizens. The policy of collectivization was wide-open for different aspects of freedom, including religion. Before the Bolshevik Revolution in 1917, as Bryan (1942) sees, the Orthodox Church was virtually a significant part of the state. It had accepted certain privileges offered by the state in return for services rendered by the church. The ROC's situation and destiny were broadly tied up with that of the Tsar. But when the revolution was over, the Russian Church was isolated from the rest of Christendom and lacked a large fellowship that might have given support and supply (Bryan, 1942).

On 23 January 1918, a separation decree was imposed upon all churches and any religious aspects ought to have been separated from the state and particularly from the educational system. Furthermore, the decree deprived churches of the right to hold property at the mercy of the state. The church was legally and officially allowed to work but its position was ambiguous (Petrenko, 2012). The only function the church could perform was to consolidate its influence over the Orthodox Churches in the Eastern European countries, which were under the control of the Soviet state, particularly after the Second World War (Petrenko, 2012). The Communists were extremely cruel against any religious aspect; some churches were nationalized, and others turned into gulags and prisons. Anti-Christianity was taught in schools, and many priests and monks and every person in charge of the church were executed. It was a definite philosophy of life. The Communists were believing that life has a materialistic basis and that the idea of God is susceptible to a scientific explanation. They claimed that the idea was exploited by bishops and tyrants to enslave men's minds and make them more acquiescent and obedient to the will of their masters, claiming that religion had proved its hostility to science and was inert in the face of human exploitation (Bryan, 1942). Religious teachings were considered mere superstitions that originated during the golden age of the church in a pre-revolutionary society that influenced minds and attitudes. All this could not be accepted in the revolutionary logic of the Communists, but after the collapse of the communist camp and the Soviet empire, many rules were changed followingly. Aspects of religious freedom and religious observance increased dramatically in the new Russia and the Orthodox Church began to enjoy official favor as the national church. Many observers (Bentwich, 2015; Dalton, 2013; Rose \& Urwin, 1969) believed that religion would provide a basis for political mobilization, but this has not eventuated (White \& McAllister, 2000).

After a long period of suppression, there were substantial changes in the formal position of the churches in post-Soviet Russia. A kind of religious freedom appeared, following the fall of the atheistic Soviet system that left a spiritual vacuum seen to be a suitable and fertile ground for the church's missionaries. Despite this religious freedom, the ROC was afraid of being short-circuited and 
becoming a mere religious entity in Russia, not the dominant religious institution and culture shaper. Consequently, it would lose its chance to rebuild its social influence. In response, in 1997 the ROC succeeded in pushing the government to pass a law that restricted the freedom of any other religious practice and faiths considered of foreign origin. This 1997 supplemental law on religion called the Law on Freedom of Conscience does not recognize a state religion, yet its preamble identifies Russian Orthodox Christianity, Judaism, Islam, and Buddhism as "traditional religions" and recognizes the special contribution of Orthodoxy to the history of Russia and to the establishment and development of Russia's spirituality and culture. As a result, this new supplemental law put the ROC back in a position suitable to shape the emerging national culture (Coyer, 2015).

President Vladimir Putin, who succeeded Boris Yeltsin in 1999, shrewdly noted that the ROC could play a useful role in enhancing nationalism and identity building. Consequently, the influence of the Russian Orthodox Church played a critical role in Russia's transformation as reflected in the media (Simons, 2004). Additionally, ROC shared his view of Russia's role in the world, thus it was seen an opportunity for Putin to get started working toward strengthening the church's role in Russian society. President Putin wasted little time in selecting the influence of the ROC that was proximately intertwined with the Russian state since the 1300s, except for the 74 years of the Soviet rule from 1917 to 1991 (Spencer, 2017), where the Russian church was seized and marginalized. The state support of this powerful church points out to Russia's wish to move away from the secular West, and back to a nostalgic era of the Tsarist Empire, when the strong autocratic state church defined public life-as the church was used by officials as a soft power-to spread Russian supremacy over an ever-wider swath of geographic territory (Spencer, 2017). Apparently, as the role of the Russian Orthodox Church has been considered significant in Russia's foreign policy after the collapse of the USSR, the ROC itself is seen as well as a geopolitical tool to promote Russia's ascendancy in world affairs.

Some questions are raised here, such as, how does the Orthodox Church articulate the national identity of Russia even though religion played a very limited role in structuring Russian politics in the late 1990s? Also, how it was possible that trust in the Orthodox Church, which had fallen after 1994, began to increase again a year later? Why did religion generally have a weak influence on political conduct in immediate post-communist Russia (1994-1995)? This weak influence of the church may have several sources. First, the adherents of the church were witness to a transferable political stage full of doubts in a short period of time, as just a few years before the church was under suppression. Also, the church itself lacked the set of conditions to be engaged in politics and influence political behavior. The second reason is explained by the almost total absence of civil society, underpinned by a functioning market economy and regulated by a liberal democratic state (White \& McAllister, 2000: p. 370). By the time of the ascent of President Putin in early 2000, the ROC's position increasingly contributed to de- 
fining public life and shaping foreign policy to a certain extent.

The above-mentioned realities manifest a need for the correlation between cultural and spiritual aspects in Russia's national security strategy (NSS) and foreign policy concept (FPC). A widespread central concept was adopted in the interest of spiritual values; this concept has rooted itself at the top of the strategic planning of Russia, in both the NSS and the FPC (Blitt, 2011). It exhibits how spirituality has penetrated the rhetoric of Russia's NSS and Russia's foreign policy, in a time-challenged to change. Corresponding to this Russian vision, politicians and government officials made explicit connections between Russia's culture and the ROC. As reported by Sergey Lavrov (Russian Foreign Minister since 2004), the cooperation of Russian officials with the Russian Orthodox Church has been experienced for a long time as one of the domestic diplomacy traditions. Also, Russia's Ministry of Foreign Affairs is closely linked with the ROC, to which the majority of Russians are affiliated. Lavrov added that Russia's government values are influenced by the ROC in the formation of the Russian state, and recognized its role in shaping culture and consciousness of the multi-ethnic and multi-religious Russian community. Lavrov said: "We also commend the role played by the Russian Orthodox Church in the life of present-day Russia as one of the consolidating forces of Russian society" (Blitt, 2011: p. 375). This, in turn, has led to a bizarre reality in which a secular state defends the rights of others on behalf of traditional values and a religious body called the Russian Orthodox Church outside of the country. As a matter of fact, Russian leaders see the ROC as a political opportunity to be grasped in a timely fashion. In confirming this tie-up between Russia's foreign policy and the ROC, whereby the state and the church operate in tandem to achieve Russia's foreign policy objectives, in such a manner, Sergey Lavrov described the ROC that: "as nothing less than a huge mainstay of government actions in this sector" (Blitt, 2011: p. 381). Zarakhovich (2007), in an article in Time, stated that Putin's aim was for the take over of the Russian Orthodox Church Outside Russia (ROCOR) ${ }^{1}$ by Moscow Patriarchate with the purpose of launching a new globalized church as $\mathrm{Pu}$ tin's main ideological arm and a vital instrument in Russia's foreign policy. As ROCOR is recognized as semi-autonomous, it is among the Kremlin's set of soft geopolitical powers that have paved some difficult roads in the process of Russia's foreign policy.

Looking precisely at the recent interactions of Russkiy Mir ${ }^{2}$ (Russian World) with the ROC, the relationship is obviously increasing, as Laine and Saarelainen (2017) have argued that the "Russian World" concept functions as a geopolitical metaphor that resembles the concept of Holy Rus. This reinforces the idea of spiritual connections among all Russians, not only within the borders of today's Russian Federation but far beyond, sometimes even including the entire Slavic-speaking population.

${ }^{1}$ ROCOR was established in the early 1920 s as a real independent ecclesiastical jurisdiction of Eastern Orthodoxy, and since 2007 it became a semi-autonomous part of the ROC.

${ }^{2}$ Russian concept Русский мир means in English "Russian World", or "Russian Peace". 
Spiritual security is also an external concept and related to the role of the ROC abroad. As prime minister under Medvedev's administration, Vladimir Putin said in 2009 that: "In the dialogue with other Sister-Churches, the Russian Orthodox Church has always defended and hopefully will continue to defend the national and spiritual identity of Russians" (Payne, 2010). By the early 2000s, religion took a position in politics as long as it went hand-in-hand with the main objectives of Russia's foreign policy. Payne (2010: p. 713) focuses on three roles that the ROC is providing. First, along with Putin's understanding of "spiritual security", the ROC has consolidated its rule over the Russian diaspora. Secondly, the relationship has provided the opportunity for the reacquisition of Russian property that was lost during the Communist period. And thirdly, through its relationship with the RFM, the ROC has been able to expand the influence of the Russian government throughout the world. Alicja Curanovic observes the explicit and implicit impact that Russia's religions have on its foreign policy decisions, arguing that an often-overlooked factor (religion) is, in reality, an important ideological and cultural determinant on Russia's behavior both within the region (locally, regionally) and in the international scene (Huemmer, 2014).

Historically, the use of religion as a tool to justify foreign interventions has a deep-rooted tradition, especially in nineteenth-century Russia. The protection of religious minorities in the Ottoman territories was one of the early cases of legally accepted humanitarian interventions (Kroll, 2016). It was one of the instruments used to implement and justify the politics of unequal relations. Intervention in the name of minorities is, of course, a political question, but also has the potential to move the demarcations of legal principles (Kroll, 2016). For the case of the ROC, understanding of its role as a global actor in international politics and its ties with Russia's foreign policy is somehow misleading. Religion in general and particularly the ROC has become an outpost of Russia's foreign policy in achieving its geopolitical ambitions and objectives. However, it is too early to give a clear definition of the relations between the Russian Orthodox Church and Russia's foreign policy as the topic is still under the search. For instance, the ROC agrees to be sometimes used by the state as a political and diplomatic tool in such international political situations when Russian involvement could otherwise be considered a Russian intervention (Tserpitskaya, 2005). Providing conceptual and ideological justifications for the Russian agenda in world affairs has led Kremlin officials to function at different institutions for that purpose, in terms of making such institutions a religious or pro-government think tank (Petrenko, 2012). Thus, the church has supported and provided justifications for Russia's official position on the Western military interventions in the former Yugoslavia, Iraq, Afghanistan, and Syria.

The question of religious extremism and how it emerged as a threat to Russia's national security is another topic which requires a serious investigation. Many aspects of Russia's social and political composition have been changed under the presidency of Dmitry Medvedev from 2008 to 2012. In fact, Medve- 
dev's national security strategy was an extension of the strategic vision of Putin in order to beat out any emerging threat to Russia's national security (Blitt, 2011). For instance, the activities of intelligence agencies, foreign governments, different organizations, and individuals are categorized as the major menaces to Russia's national security, and all should be beaten out, particularly the activities of terrorist organizations. ${ }^{3}$ Russia needed to fight any kind of intruder religious organizations and NGOs, by creating strategic hurdles as bureaucratic rules and other tactics and strategies taken directly from Putin and enthusiastically supported by the Orthodox Church (Blitt, 2011: p. 370). As this strategic vision continues to be operated till now as a preventive way against any probable threat, Russian politicians go back to the ROC for making a close alliance for the purpose of reviving Russian nationalism and to bring back Russian Tsart golden era to consciousness on one side, and to beat out these foreign religious organizations on the other side. Therefore, both Putin and Medvedev continued to assert that modernized Russia should rely on the Orthodox faith (Interfax, 2010). In order to emphasize the spiritual danger facing Russia, Putin, in the 2000 National Security Concept, drew a tight connection between religion, culture, and nationality and stressed the central role of the ROC in Russian culture and social order (Payne, 2010).

\section{Russia's Anti-Terror Front in the Middle East: The Case of Syria}

Dmitri Trenin argues that the Middle East is important to Moscow for two main reasons: 1) shared physical proximity; and 2) the Muslim factor that Russian Muslims have the connected religious brotherhood and the sense of unity with Muslims in the Middle East (Trenin, 2010). Thus, Russia wants to extend its religious discourse in its foreign policy extension from the Caucasus (Chechnya) to the Middle East (Syria). Russia does not want to repeat the same mistakes that did happen in Libya when Russia lost Libya as a geopolitical façade in front of NATO expansionism in the Middle East and North Africa (MENA). So, under the slogan of "learning in Libya and acting in Syria", Russia looks to regain its status as a key power in the Middle East. The ideology of Russia's uniqueness in Eurasia (Eurasianism) has clearly re-emerged in the Middle East as well.

On the contrary to other regions such as Eastern Europe and Central Asia, which are in Russia's foreign policy priorities, the people of the Middle East are known for their religious peculiarities, and Islam comes to the fore as the prominent and widespread religion in the region. Observing how Russia's foreign policy has extended its religious discourse from the Caucasus to the Middle East, the Russian philosopher Alexsander Dugin (who is often identified as the brain of Putin) argues that Russia's underlying superpower assumptions go hand in hand with a geostrategic creed concerning Eurasia. This creed seeks to unite the Slavs and Central Asian Muslims from the borders of the Middle East against

${ }^{3}$ Ex: Scientology was considered as extremist besides the followers of Nursi group. 
NATO. At the same time, it seeks to create an alliance with Iran and states with a similarly nationalist ideology such as Syria and Libya (Dugin, 2004). But now as it is known that Russia has lost Libya to the West after the Gaddafi's regime was damaged by rebels supported by NATO. Hence, Russia looks to enhance its geopolitical milieu in countries that are still under the Russian alliance circle, particularly Syria.

According to Russian leaders, Jihadist groups in the Caucasus and the Middle East are logistically and spiritually linked, as they cooperate to internally destabilize the security of the Russian Federation, and externally as a menace to Russia's geopolitical interests in both regions. These Jihadist groups constitute not only a local or regional danger but also a global threat to common international security. So, Russia tries to play the chord of the global War on Terror to be a pioneer in this policy besides the U.S, as this war was declared since September 11th, 2001. In fact, Russia has played a significant role in these conflicts. From the outset of the civil war in Syria, Russia started acting as an intermediary of this conflict, which ended with military action in September 2015. Thorough ongoing and in-depth discussions over Russa's foreign policy strategies related to Syria formed the necessity in the analysis of the main reasons behind the decision of Russia's foreign policy to get involved in the Syrian case. A form of relationship between Russia and the West has evolved in terms of fighting terrorism in the region. Russian politicians, including President Vladimir Putin, have frequently called for creating a global anti-terrorist coalition and putting differences aside. As Sergey Shoygu, the Russian Minister of Defense stated that: "We will, again and again, call for the unification of the military community in the fight against terrorism" (Klimentyev, 2017), this apparently refers to a fact that Russia does not want to be alone in carrying all the burdens of anti-terrorism strategy, even though Russia was at first driven with a logic of supremacy and domination to be a pioneer which takes the initiative to fight and defeat terrorism in the region (Klimentyev, 2017).

On September 28, 2015, and for the first time since the establishment of the UN General Assembly, Putin, touching upon the principal events and issues on the international agenda, put the fight against terrorism in the spotlight. Putin called for the creation of a broad coalition to fight terrorism, and Russian Foreign Minister Sergei Lavrov confirmed earlier that Putin's idea gained more supporters. At that time, airstrikes led by the U.S. and its allies against ISIS in Syria were not authorized by the UN Security Council and by the Syrian regime itself, while Russia got the green light to start its military and aerial campaign against terrorists at the request of the Syrian president. For a long time, Russia has been interested in the political affairs of Syria. Syria is considered the strongest allies of Russia besides Iran in the Middle East. According to Putin, the Syrian war is justified, as both Russia's and Syria's national securities are threatened by what they call Islamic terrorism. What makes Syria as a most important partner for Russia in the Arab East, refers to many causes: first, its relative independence from the West; second, its secular government; and third, 
the well-established tradition of bilateral cooperation (Kreutz, 2010).

As stated earlier, Russia's foreign policy employs many political and diplomatic tools to deal severely with issues mainly those are related to the War on Terror. One of these tools is the usage of the religious institution as a form of soft power. If we consider that Russia's foreign policy is a realist actor, so the question that still imposes itself here is: does the church have any influence on the secular political process of Russia? (Petrenko, 2012). It is allegedly claimed that some Christian denominations and institutions such as the Russian Orthodox Church are less violently thinking and acting, they are far from being fundamentalists and extremists, and are usually calling for peace and tolerance. This is held in contrast to those called Islamist Jihadist groups, which stemmed from different Islamic denominations, particularly those appearing with the outbreak of the so-called Arab Spring.

\section{The U.S. Support of Opposition and Russian Support of the Assad's Regime}

The civil war in Syria resembles a war of the interests between two superpowers, whereby everyone wants, by all means, to bring the whole region under its hegemony. In a proxy war between a U.S. Sunni alliance (Saudi Arabia in particular), and the Russian-Shiia alliance (mainly Iran) in Syria, the U.S. found itself fighting not only Syria, Russia, and Iran but, apparently, the Christians who remained in Aleppo or returned to it (Frankovich, 2017).

Amid the geopolitical confrontation between Russia and the United States and their allies, a little attention has been paid to the role of religion in the conflict, either as a shaper of Russian domestic politics or as a means of understanding the President Putin's international actions. The role of religion has long tended to get short shrift in the study of statecraft, although religion has lately known to be a kind of renaissance and played a prominent role in various areas including supporting the Russian state and Russia's current position in world affairs (Coyer, 2015). According to Coyer, religion has a limited influence on Russia's domestic and international position. However, in spite of this limited role of religious institutions, some aspects of religious policies can be observed in Russian policies. Domestically, President Putin has the support of a powerful ally with over 150 million adherents worldwide, and the head of the public affairs department of the ROC, Vsevold Chaplin, addressed a press conference in Moscow in 2015, expressing support for Russia's intervention in Syria (Al-Watan, 2015). Even today among Orthodox Christians of the Middle East, Russia enjoys a special influence as the last major center of Eastern Orthodoxy (Fuller, 2008). Furthermore, this special influence is important for Russia, particularly in its geopolitical confrontation with the West in the Middle East.

In an exclusive interview with the BBC, Russian Foreign Minister Sergei Lavrov said that his country believes that the U.S. may be tacitly supporting Jihadist rebels in Syria. He said that the U.S. had broken a promise to help separate 
the powerful Jabhat Fateh al-Sham (formerly known as al-Nusra Front) and other extremist groups from more moderate rebels (Lavrov, 2016). Lavrov was asked if the Americans had lost the control of both, Americans themselves and events in Syria. He answered that if they don't present any evidence to the contrary, either they are driven by al-Nusra or they basically supported these terrorist organizations. Lavrov continued his speech by saying, "If you take history during Reagan's administration, al-Qaeda' was born because the United States was supporting Mujahideen in Afghanistan" (Lavrov, 2016).

The yearning for being a forerunner in fighting terrorism compelled Russia to become deeply involved in the Middle Eastern affairs under the banner of anti-terror strategy. The purported development of the ROC as a religious counterbalance against ISIS appeared to be a new urgency as Russians and other nationalities of the former Soviet Union (CIS) make up an increasing percentage of the recruits of the radical group ISIS (Spencer, 2017). These new recruits from the Caucasus were considered a real threat to Russia's national security and national interests wheresoever they exist. Russia already has a history of the Islamic insurgency in the Caucasus due to two Chechen Wars. However, the threat of ISIS to Russia's social and political integrity is arguably far dangerous and greater than that posed by what is termed the Chechen rebels.

In a war of alliances (Alliance rivalry), Vladimir Putin has decided to oppose the U.S. policy of chaos actively in the Middle East. According to Russian leaders, the U.S has created a huge mess in the region, and it is a Russian duty to clean it up. Russian military help (hard power) against terrorism in Syria can be seen as an act of Eurasian geopolitics. Consequently, Syria is located at the center of the battle between the representatives of a unipolar (U.S.) and a multi-polar (Russia) world order. Alexander Dugin said that Syria is Russia's external line of defense ${ }^{4}$. Putin's message from his last visit to the Khmeimim Russian military base in Syria's Latakia province on 11 December 2017, confirms that the military operations have been successfully done, and now it is the suitable time to change this to a political operation with peace settlements. Until today, Khmeimim and Tartus continue as the main bases for Russia in the Middle East to extend its sphere of influence. Also, it is a message to the West that Russia has achieved its main objectives. Moreover, it is apparent that Russia confirms its loyalty to its allies as long as it stays loyal and it didn't back off. Also, it underlines that it is a sincere ally, as contrary to the U.S, Russia does not relinquish its allies mainly in the critical circumstances. Additionally, Sergei Lavrov confirmed that if Russia didn't intervene in Syria, Damascus was about to fall (Lavrov Says Damascus Weeks from Falling When Russia Intervened, 2017).

\section{Russia's Realistic Approach to Fight Terrorism}

Russia has nothing to lose due to severe criticism from the international community, as Russia is used to defying it. Seemingly, Russia did not care about in${ }^{4}$ See an interview with Dugin by GermanCenter (2016) on 9 December 2016. Alexandr Dugin,

"Why we fight in Syria", ZUERST. 
ternational opinion when it decided to become involved in the Middle East, as we can observe in the case of Syria when it started its military land and aerial campaign to defeat terrorist groups under the blessing of the ROC. Putin met his Syrian counterpart, Bashar al-Assad, in Sochi on 21 November 2017, and said to him that Syria and Syrian people have been tested in the hardest ways, but he confirmed that the defeat of terrorist groups is inevitable and, in the near future, Russia will put a full stop to terrorism (Inessa, 2017). Generally, Russia was no stranger to the matter of war, as experienced previously in Georgia and Ukraine. Also, according to Caspian Report, Moscow did not want to put its international reputation at stake in a proxy war that geopolitically does not necessarily mean that the actors have interests for a region that is, in reality, a mere battlefield whereby these actors flex their muscles. This happens now in Syria and earlier happened in Afghanistan in the 1980s (Caspian Report, 2013).

Moscow has adopted a realistic approach in dealing with such issues to keep its interests in sync. In Syria, the Russian officials do not care whether Assad's regime wins or about guaranteeing Christians to be safe as the ROC claims. They also do not care about a large number of dead among unarmed citizens. De facto, Russia's main interests are to guarantee its geopolitical milieu, chiefly its military presence at the coasts of warm-waters (Mediterranean Sea) (Delman, 2015). Furthermore, Russia wants to divert the West, and particularly the US, from Moscow's sphere of influence by entangling the US in conflicts throughout the Middle East. This, in turn, would give Russia more maneuverability to reassert its influence in the former Soviet Union. Moscow wants to strengthen the image of a Russian superpower, while at the same time portraying the U.S. as a declining power. Russia at first considers Syria as an asset to its geopolitical milieu in the Middle East, but the escalation and the accumulation of complex events in the region have shown how this geopolitical asset is probably being a dangerous liability.

The role of the ROC in supporting Russia's military campaign is obvious, to the extent of blessing the Russian arms by naming the aerial campaign a "holy battle" as pictures of some ROC's bishops were shown by the media. Earlier, to make a justification for the annexation of Crimea, Putin invoked the history of the ROC for this purpose, and he described the site of Prince Vladimir's conversion to Christianity in the Crimean city as Russia's Jerusalem (Tharoor, 2015). The ROC's worldview, as the head of the church's public affairs department, Vsevolod Chaplin indicated, extends south into the Middle East. Since the outbreak of the Syrian civil war, the Russian Orthodox Church has emphasized on the need to protect the region's Christian minorities and lent aid to its remaining (Tharoor, 2015). Similarly, in the case of the annexation of Crimea, Putin used religion as a narrative to justify Russian engagement (Kroll, 2016).

Vladimir Putin's relationship with the ROC is well-documented, and the ROC's leader, Patriarch Kirill, has famously called Putin's presidency "a miracle from God" (Melton, 2016). Melton states that many believe that the KGB's re- 
placement, the $\mathrm{FSB}^{5}$, still has a significant influence over the ROC. These connections allow Putin to use the church for soft power exercises that is to improve Russia's image abroad (Melton, 2016). Putin today is not only a powerful political actor but-like the Tsars-a religious one. In his speeches, he presents himself as a defender of the Christian values abandoned by the degenerate West (Wargas, 2015). The claim of protecting the Christian minorities led the Patriarch Kirill of the ROC to declare during his Christmas interview with the Rossiya-1 TV channel that, besides solving some issues such as preventing national security from any terrorist threat, there was a very important point in Russia's participation in the Syrian conflict that is to protect its Christian minorities (VoicesfromRussia, 2018). The fight against ISIS, which is considered an armed religious group supported by the West, compelled the ROC to declare that it is legitimate to fight against it. Patriarch Kirill stated in an official interview that ISIS is a reaction to the secularization of society, particularly in the West (Spencer, 2017). When Russia began its military operations (hard power) in Syria, the leaders of the ROC explicitly declared their support for Moscow's decision. In an official statement, Patriarch Kirill said, "The Russian Federation has made a responsible decision to use armed forces to defend the people of Syria from the sorrows caused by the arbitrariness of terrorists. We believe that this decision will bring peace and justice to this ancient land" (SerbianOrthodoxChurch, 2015).

Putin appears to agree that the Russian intervention into Syria was a "holy war", while quietly ensuring that he does not want to be it an anti-Islamic agenda. The Russian President has his own local Muslim minorities of 25 million and does not want to create any local trouble to worry about (Wargas, 2015). Thus, the concept of a blessed war instead of holy war looks rational, as holy war signifies a civilizational conflict and inter-religion war, but blessed war predominantly means a just war. Not even all Christians in Syria like to call it "holy war" against ISIS because they know, what does the word really mean. Moreover, $\mathrm{Pu}$ tin does not want to be a lucid opponent to Islam as a major religion of the Middle Eastern countries, as Russia's strongest allies are from these countries, mainly Iran and Syria. Russia does not want to make Russian Muslim minorities an obstacle, as long as Russia looks to regain its status in the region.

From a Western secularist perspective, the relationship between Russia's foreign policy and the ROC is mutually beneficial and it could be a red flag. The church must have corrupted by the Kremlin to secure more political power, and Putin is surely not sincere in his alleged Orthodox beliefs. Melton (2016) argues that if Putin was no longer in power, the Russian masses would embrace Western secularism. Archpriest Chaplin revealed that the ROC and the Kremlin together view the upsurge in conservative religious observance in Russian public life as a barricade against the influence of the secular West that is corrupt, also a driving force behind Russia's intervention in the Syrian civil war. Vsevolod ${ }^{5}$ Federal Security Service of the Russian Federation is the principal security agency for internal security of the Russian state, counterintelligence, and the fight against organized crime, terrorism. 
Chaplin stated that: "The fight with terrorism is a holy battle and today our country is perhaps the most active force in the world fighting it" (Bennetts, 2015).

The ROC demonstrates a double standard policy when it looks only for the safety of the Christians at the cost of other religious groups. It should be taken into consideration that Syria's population consists of nearly 90 percent Muslims and 10 percent Christians, which is apparently a discrepancy and contradictory to the principles of the ROC. Although Patriarch Kirill said that Russia has made a responsible decision to use armed forces to defend the people of Syria from terrorist groups, the ROC still contradicts itself. According to the Orthodox tradition, "a human being preserves his God-given dignity and grows in it only if he lives in accordance with moral norms" (Russian Orthodox Church, nd). Probably, if Syria does not have any Christian then the ROC will find no chance for its support except for getting some privileges that it looks for, either the chance exists or not. Obviously, the ROC like Russia's foreign policy shows its realistic approach in supporting and even blessing the Russian military operations in Syria under the pretext of fighting against all terrorist and extremist groups that might be a threat to all, particularly to Russia's national security. But what is behind the ROC's enthusiastic support for achieving a set of purposes can be summarized in the following: 1) to get closer to Russian leaders in a mutual beneficial relationship; 2) to confirm its spiritual and political existence; 3 ) to raise a self-confidence in terms of being a strong spiritual representative to the Orthodox Churches across the world; 4) to be a primus inter pares among other Orthodox Churches in the so-called religious diplomacy to somehow show that they are far from being extremists in as much as they are participating in fighting extremism; and 5) to counteract a dangerous rivalry from any other religious-political power. In fact, talking about the geopolitics of religion leads many to believe that clergymen, bishops, and priests are just politicians with Machiavellian agendas.

If protecting the Christian minorities in Syria is among the main objectives of Russia's military intervention, so why did the U.S. not intervene to protect these minorities against any threat or attack from terrorist and extremist groups ${ }^{6}$ ? Or should we suggest that the U.S. and the West, in general, don't care about the affiliations of these religious groups, mainly Christians whom the majority of Western citizens belong to? In reality, the Patriarchate of Moscow seems to be a client or even a puppet of the Kremlin, although powerful Russian officials routinely meet with church leaders (Wargas, 2015). The ROC also agrees to be sometimes used by the state as a diplomatic tool in such international political situations when Russian involvement could otherwise be considered a Russian intervention (Tserpitskaya, 2005). Considering all this old-fashioned realpolitik, it would be easy to say that Putin had no interest in the plight of Christians,

${ }^{6}$ The U.S used to help the opposition forces against the al-Assad regime which considered illegitimate and a real threat to the Syrian people, it was supposing that it was only a question of time for the regime to fall, but it has prevailed with Russia's intervention. 
while the main interest is to save Russia's national security and identity and to regain Russia as a superpower in world politics.

Apparently, as Joseph Stalin did before, Kremlin is actually in need of all Russian components from institutions to individuals. And all that can give help to internally ensure the national security and to externally regain Russia's world status. It is clear how Russia's foreign policy used the ROC as a political tool due to many reasons as follows: 1) to get further support to Russia's foreign policy engagement in world politics, and to support Russia's aspirations to be a power separate from the West, as Russia needs an instrument that will serve as the unifying cultural factor in its identity; 2) to gain some legitimacy in their political processes to be reckoned with, in terms of fighting terrorism as a global phenomenon that threatens the international security; 3) to stimulate and incite Russians mainly those who are more adherents to the ROC to be satisfied with the internal and external politics of their government's leaders; and 4) to get deeply involved in such regions and countries that are considered an extension of Russia's sphere of influence in a new geopolitical milieu whereby Russia looks for domination.

\section{Conclusion}

Russia is more ineluctably interested in the politics of Muslim countries than ever before, particularly in the Middle East. During the Cold War period, the Middle East was an area of interest clash between the Eastern and Western blocs. To the present, this struggle continues due to the unquestionable geopolitical and geostrategic importance of the Middle East as a prominent target of great powers. In the post-Cold War period, the Russian Federation came to replace the Soviet Union and to regain its world status as a superpower in the international system by competing with the United States for hegemony in the region. Russian leaders adopted a set of policies and strategies to defeat political, economic and social challenges there, mainly those related to the question of national security and in relevance to the sphere of influence. One of these strategies is the anti-terror front to fight against terrorism, and in a (un)holy alliance under the so-called geopolitics of religion, Russia goes hand in hand with the Russian Orthodox Church on that strategy.

In a nutshell, the Russian leaders employ the ROC in political terms as a soft power tool for promoting Russia's foreign policy, as a way to achieve its national interests and to guarantee its national security. This was made clear with the involvement of the ROC in blessing the Russian military intervention in Syria as a hard power since 2015, even as the rate of civilian casualties increased day by day due to these military operations on civilian people, and how the ROC contradicts its Christian principles. In fact, both the Kremlin and the ROC's leaders want to make Russia geopolitically great again, as the Patriarch Kirill argues that they seek to regain Russia's nostalgia and reliving an optimal epoch when Russia's identity was safe.

Putin has anchored his political brand in religious nationalism, centered on 
the Russian Orthodox Church, and it has become a key agent in spreading Putin-friendly patriotic propaganda. Due to boosting and strengthening Russia's national identity to be internally a cohesive force and externally stronger and more willing to regain its world status pragmatically makes this alliance. What Putin has done in Syria till now is geo-strategically logical, as he sees the extremist groups fighting against the Al-Assad regime as a menace to Russia's political, economic and military presence in Syria. Additionally, in terms of Russia's national security, Russia has experienced a great menace of fighting groups at home in Russia and exactly in the Caucasian region. Martin Mccauley (Al-Jazeera, 2016) argues that Putin militarily intervened in Syria because he sees that ISIS is an existential threat to Russia, and if ISIS wins in Syria it will move to the Caucasus (Narochnitskaya, 2016). This would greatly destabilize Russia's national security.

The main problem with the ROC is not whether God gives governments the right to militarily protect their national interests, but the political conclusion that the best way to ensure peace in Syria is by allowing a war criminal-Bashar al-Assad-who is incapable of controlling Syria alone to remain in power, as Melton (2016) has stated. If Russia had not intervened, the Al-Assad regime would have fallen in the early stages of the Syrian upheaval. It is argued that Kremlin officials do not care whether Al-Assad's regime stays or goes; rather, the main objective is to protect Russia's national security and to guarantee its geopolitical milieu, and in particular its military presence.

Finally, it is worth mentioning that this article has some limitations as it focuses on a specific region, Syria and the Middle East, in order to analyze the relationship between religion and the Russian state. Thus the conclusions suggested in this paper are relevant to this specific area only and also means the country's dominant religion, Christianity, while mentions the "religion." At the same time, the attitude of the state could differ in relation to other minority religions, such as Islam, Judaism or Buddhism. Thus, in order to better study the topic in the future, the role of other religions in policy-making of the Russian Federation could be considered.

\section{Acknowledgements}

This paper is supported by Research Grant P-RIGS18-004-0004 entitled "The Decolonisation of Social Sciences from a Eurocentric Approach: Construction of an Integrated Worldview" from International Islamic University Malaysia. The project suggests a new integrated approach in studying some social sciences' phenomenon such as the relationship between religion and state. This small-scale grant (RM5000) is offered to assist the publication expenses of the University's staff.

\section{Conflicts of Interest}

The authors declare no conflicts of interest regarding the publication of this paper. 


\section{References}

Al-Jazeera, A. (2016). Transcript: Natalia Narochnitskaya on Putin's Russia. https://www.aljazeera.com/programmes/headtohead/2016/02/transcript-natalia-naroch nitskaya-putin-russia-160201131109252.html

Al-Watan, D. (2015). Russian Warplanes over Syria: A Religiously Sanctioned Affair [Press Release]. https://english.alwatanvoice.com/content/print/789059.html

Bennetts, M. (2015). The Kremlin's Holy Warrior. http://foreignpolicy.com/2015/11/24/the-kremlins-holy-warrior-chaplin-putin-russia-t urkey-syria

Bentwich, N. (2015). The Religious Foundations of Internationalism: A Study in International Relations through the Ages. ¡Abingdon-on-Thames: Routledge. https://doi.org/10.4324/9781315671079

Blitt, R. C. (2011). Russia's Orthodox Foreign Policy: The Growing Influence of the Russian Orthodox Church in Shaping Russia's Policies Abroad. University of Pennsylvania Journal of International Law, 33, 363-460. https://doi.org/10.2139/ssrn.1725522

Bryan, F. C. (1942). Religion and Russia. Baptist Quarterly, 11, 106-113. https://doi.org/10.1080/0005576X.1942.11750618

Caspian Report (2013). Why Does Russia Support Syria's al-Assad? https://www.youtube.com/watch?v=lW0HP7Xd2rs\&t=148s

Cheskin, A. (2017). Russian Soft Power in Ukraine: A Structural Perspective. Communist and Post-Communist Studies, 50, 277-287. https://doi.org/10.1016/j.postcomstud.2017.09.001

Coyer, P. (2015). (Un)Holy Alliance: Vladimir Putin, the Russian Orthodox Church, and Russian Exceptionalism.

https://www.forbes.com/sites/paulcoyer/2015/05/21/unholy-alliance-vladimir-putin-an d-the-russian-orthodox-church/\#e01179427d5b

Curanovic, A. (2012). The Religious Factor in Russia's Foreign Policy: Keeping God on Our Side. Abingdon-on-Thames: Taylor \& Francis.

https://doi.org/10.4324/9780203133279

Dalton, R. J. (2013). Citizen Politics: Public Opinion and Political Parties in Advanced Industrial Democracies. Washington DC: Cq Press.

Delman, E. (2015). The Link between Putin's Military Campaigns in Syria and Ukraine. https://www.theatlantic.com/international/archive/2015/10/navy-base-syria-crimea-pu tin/408694

Dugin, A. (2004). The Foundations of Geopolitics: The Geopolitical Future of Russia (Hatim, E., Trans., Vol. 1). Beirut: Dar al-Kitab al-Jadid.

Frankovich, N. (2017). Deposing Assad Could Hurt Syria’s Christians. https://www.nationalreview.com/corner/syrian-civil-war-assad-christians-oppose-effor ts-depose-him

Fuller, G. E. (2008). A World without Islam. Foreign Policy, 164, 46-53.

GermanCenter (2016). Alexandr Dugin: "Why We Fight in Syria”. ZUERST.

Graziano, M. (2018). What Is the Geopolitics of Religions? https://www.resetdoc.org/story/what-is-the-geopolitics-of-religions

Huemmer, A. (2014). The Religious Factor in Russia's Foreign Policy. Abingdon-on-Thames: Taylor \& Francis. https://doi.org/10.1080/09668136.2014.912848

Inessa, S. (2017). Where's NATO? Putin, Assad Win Syrian War [Video File]. https://www.youtube.com/watch?v=oeVLCL0b4GA 
Interfax (2010). United Russia Considers Orthodoxy as a Moral Basis for Modernization. http://www.interfax-religion.com/?act=news\&div=6946

Klimentyev, M. (2017). Putin's Proposal to Create United front against Terrorism Gains More Supporters [Press Release]. https://sputniknews.com/politics/201702101050540470-united-front-terrorism-lavrov

Kreutz, A. (2010). Syria: Russia's Best Asset in the Middle East. Russie. Nei. Visions, 55.

Kroll, S. (2016). Humanitarian Intervention: Religion as a Reason for Intervention. Religion and the Public Sphere.

Laine, V., \& Saarelainen, I. (2017). Spirituality as a Political Instrument: The Church, the Kremlin, and the Creation of the "Russian World".

https://www.academia.edu/34548554/Spirituality_as_a_political_instrument_The_Chu rch_the_Kremlin_and_the_creation_of_the_Russian_World

Lavrov Says Damascus Weeks from Falling When Russia Intervened (2017). Press Release, Polygraph.info.

https://www.polygraph.info/a/russia-syria-lavrov-damascus/28267150.html

Lavrov, S. (2016). Russia's Sergei Lavrov: BBC Interview in Full. BBC Interview: BBC World News TV.

https://www.bbc.com/news/av/world-middle-east-37523229/russia-s-sergei-lavrov-bbc -interview-in-full

Melton, M. (2016). Russian Orthodox Church's Flawed Syria Policy.

https://providencemag.com/2016/02/russian-orthodox-church-flawed-syria-policy

Narochnitskaya, N. (2016). Putin’s Russia. Al-Jazeera.

https://www.aljazeera.com/programmes/headtohead/2016/02/transcript-natalia-naroch nitskaya-putin-russia-160201131109252.html

Pavlovich, D. S. (2007). Russian Orthodox Church and State Institutes of the Russian Federation: Mechanisms of Political Interaction. PhD, Moscow: Moscow State Pedagogical University.

https://translate.google.com/translate?hl=en\&sl=ru\&u=http://cheloveknauka.com/russ kaya-pravoslavnaya-tserkov-i-gosudarstvennye-instituty-rf-mehanizmy-politicheskogo -vzaimodeystviya\&prev=search

Payne, D. P. (2010). Spiritual Security, the Russian Orthodox Church, and the Russian Foreign Ministry: Collaboration or Cooptation? Journal of Church and State, 52, 712-727. https://doi.org/10.1093/jcs/csq102

Petrenko, G. (2012). Influence of the Russian Orthodox Church on Russia's Foreign Policy.

Rose, R., \& Urwin, D. (1969). Social Cohesion, Political Parties and Strains in Regimes. Comparative Political Studies, 2, 7-67. https://doi.org/10.1177/001041406900200103

Russian Orthodox Church (nd). The Russian Orthodox Church's Basic Teaching on Human Dignity, Freedom and Rights. Official Document. (In Russian) https://mospat.ru/en/documents/dignity-freedom-rights/i

Rutland, P., \& Kazantsev, A. (2016). The Limits of Russia's “Soft Power”. Journal of Political Power, 9, 395-413. https://doi.org/10.1080/2158379X.2016.1232287

SerbianOrthodoxChurch (2015). Russian Military Participation in Syria Should Bring Peace to Region-Patriarch Kirill.

http://www.spc.rs/eng/russian_military_participation_syria_should_bring_peace_regio $\underline{\text { n_patriarch_kirill }}$

Simons, G. J. (2004). Ideology, Image-Making and the Media in Putin's Russia. A Thesis Submitted in Partial Fulfillment of the Requirements for the Degree of $\mathrm{PhD}$ in Russian, 
Canterbury: University of Canterbury. https://core.ac.uk/download/pdf/35464317.pdf

Spencer, J. (2017). With God on Our Side: How Religion Will Shape Russia's Political Destiny.

https://nationsandstates.com/2017/05/07/with-god-on-our-side-how-religion-will-shap e-russias-political-destiny

Tharoor, I. (2015). The Christian Zeal behind Russia's War in Syria. https://www.washingtonpost.com/news/worldviews/wp/2015/10/01/the-christian-zealbehind-russias-war-in-syria/?noredirect=on\&utm_term $=.4$ ee6f59f5513

Trenin, D. (2010). Russia's Policy in the Middle East: Prospects for Consensus and Conflict with the United States.

Tserpitskaya, O. L. (2005). Russian Orthodox Church at the Russian State: Cooperation in Terms of Foreign Policy. (In Russian) http://www.soctheol.ru/avtor_art.php?id=172

VoicesfromRussia (2018). Patriarch Kirill: Russia Helped to Protect Christians in Syria. https://02varvara.wordpress.com/2018/01/08/patriarch-kirill-russia-helped-to-protectchristians-in-syria

Wargas, R. (2015). Vladimir Putin's Holy War [Press Release]. http://www.catholicherald.co.uk/issues/december-11th-2015/vladimir-putins-holy-war

White, S., \& McAllister, I. (2000). Orthodoxy and Political Behavior in Post-Communist Russia. Review of Religious Research, 41, 359-372. https://doi.org/10.2307/3512035

Zarakhovich, Y. (2007). Putin's Reunited Russian Church. Time.com, May, 17. 